\title{
Science-fiction literature as inspiration for social theorizing within sustainability research
}

\author{
Corinne Gendron ${ }^{a}$, Silvester Ivanaj ${ }^{\text {b, * }}$, Bernard Girard ${ }^{c, \dagger}$, Marie-Luc Arpin ${ }^{c}$ \\ a UQAM, Université du Québec à Montréal, ICN Business School, Canada \\ ${ }^{\mathrm{b}}$ ICN Business School, CEREFIGE, France \\ ${ }^{\mathrm{c}}$ UQAM, Université du Québec à Montréal, Canada
}

\section{A R T I C L E I N F O}

\section{Article history:}

Received 20 June 2016

Received in revised form

6 July 2017

Accepted 6 July 2017

Available online 7 July 2017

\section{Keywords:}

Social science theorization

Art

Literature

Science fiction

\begin{abstract}
A B S T R A C T
As commonly accepted, the stakes of sustainable development (SD) are altogether highly serious, complex, and diverse, spanning from changing living standards to the very future of mankind. Although it has long been argued that such complexity warrants radical change in the way "good" knowledge is conceived of and produced, it appears that much of sustainability research - including its grounding in social sciences - has yet to extend beyond the institutionalized precepts of natural science with regard to validity and credibility. In this context, this paper argues that crucial insights can be developed by opening social sciences' theorizing process to undervalued forms of knowledge including art in general, and science-fiction literature in particular. To support this argument, current non-scientific productions of knowledge are reviewed in light of alternate conceptions of epistemological value. The potential of science fiction as thought experiments and inspiration for both problematizing and theory building in the social sciences is explored. In particular, certain science-fiction texts are thoroughly examined to illustrate how current problems pertaining to firm theories and management practice may be "discovered" (or made visible) only through science-fiction hindsight. Ultimately, the research shows how this hidden potential may be employed by social research to radically stimulate theoretical imagination and benefit sustainability research.
\end{abstract}

๑) 2017 Elsevier Ltd. All rights reserved.

\section{Introduction}

As is commonly accepted, the stakes for sustainable development (SD) are altogether highly serious, complex, and diverse, spanning from changing living standards to the very future of mankind. Whereas it has long been argued that such complexity warrants radical changes in the way "good" knowledge is conceived of and produced - see, e.g., Jantsch (1972)'s purposive university, Rittel and Webber (1973)'s wicked problems, Funtowicz and Ravetz (1993)'s post-normal science, and/or Nicolescu (1996)'s transdisciplinarity - it appears that much of sustainability research (including its grounding in the social sciences) has yet to extend beyond natural science's broadly established precepts of validity and credibility, namely, what

\footnotetext{
* Corresponding author.

E-mail addresses: gendron.corinne@uqam.ca (C. Gendron), silvester.ivanaj@icngroupe.fr (S. Ivanaj), marie-luc.arpin@polymtl.ca (M.-L. Arpin).

$\dagger$ Diseased.
}

Jean-Louis Le Moigne (2012) identifies as institutional science's implicit social-epistemological contract or ideology.

As typically illustrated by the hitherto unresolved issue of "scientification" in life cycle assessment (LCA) also known as the LCA "value debate" ${ }^{1}$ - what may be understood

\footnotetext{
1 At the turn of the century, a debate regarding subjectivity emerged within the field of LCA, mainly through the pages of the International Journal of Life Cycle Assessment. At the heart of the so-called "value debate" lay the question of how to cope with the newly exposed prevalence of value-laden choices within LCA while seeking to avoid compromising the tool's building recognition and scientific credibility. Until the mid-1990s, an implicit understanding had indeed prevailed, according to which an entirely neutral procedure could be devised for quantifying the lifecycle impact of products (Owens, 1998). Within this paradigm - which in many ways is still rampant today -, LCA had been represented as a value-free methodology and researchers strived to produce utterly unbiased and reproducible results (de Haes and Jolliet, 1999). The "value debate" largely pivoted upon this last epistemology becoming explicit and controversial.
} 
as a "trained incapacity" ${ }^{2}$ on the sustainability researcher's part (or lack of imagination thereof) has prevented SD problems from being conceived of in radically creative ways. Among the familiar sustainability assessment tools in contemporary management practice, LCA is indeed appreciated for its scientific attributes as an everincreasing number of firms are building their public image based on the scientific truth claims that LCA has come to symbolize (Heiskanen, 1997, 2002; Freidberg, 2014, 2015). Against such a backdrop, a latent paradox prevails that arguably typifies all of sustainability research, which rests within the seemingly contradictory character of value-laden choices that LCA unavoidably entails, alongside the method's scientific formalism and rigor (Tukker, 2000; Hertwich et al., 2000; Freidberg, 2014, 2015). In recent years, LCA models and results have been recognized as intrinsically social (or cultural) constructs (Heiskanen, 1997, 2002; Freidberg, 2015; Norris and Revéret, 2015), at once making neutrality and reproducibility barren ideals to pursue. However, modeling subjectivity remains largely (and paradoxically) conceived of as detrimental to the method's credibility (see, e.g., De Schryver et al., 2013; Finkbeiner et al., 2014). Despite the notion that "value-based judgments, based on situated knowledge, can actually enhance the rigor, accountability, and credibility of scientific assessments", problems and formal discourses continue to be dissonantly constructed to fit within natural science's epistemological ideal.

In Hannah Arendt's terms, LCA's ordeal - or its "trained incapacity" as such - may be understood as a form of "thoughtlessness" that inhibits radical creativity or imagination. ${ }^{3}$ It indeed appears that "coming out from behind the [institutional science]

\footnotetext{
2 The idea of "trained incapacity" is borrowed from Kenneth Burke. According to Thomas O. Sloane, "Burke's primary example of perspective by incongruity is Thorstein Veblen's concept of "trained incapacity," which refers to the way in which one's very abilities can function as blindnesses." (Thomas O. Sloane, Encyclopedia of Rhetoric, "Perspective by incongruity"). Although literally absent from Veblen's work, the concept is defined in The Engineers and the Price System (1921). Veblen indeed considered that businessmen's lifelong studies of administrative precepts predisposed their decisions to be inherently flawed because they were based on a deep knowledge of over-simplified principles: "[U]nder the limitations to which all human capacity is subject it follows from this increasingly exacting discipline of business administration that the businessmen are increasingly out of touch with that manner of thinking and those elements of knowledge that go to make up the logic and the relevant facts of the mechanical technology. Addiction to a strict and unremitting valuation of all things in terms of price and profit leaves them, by settled habit, unfit to appreciate those technological facts and values that can be formulated only in terms of tangible mechanical performance..." (Veblen, 1921: 26). A similar relationship may be observed today between the primacy of methodological habits within institutional science and the relevant epistemological considerations (or "manner of thinking") with which it has increasingly become out of touch.

${ }^{3}$ For H. Arendt, "thoughtlessness", or the "total absence of thinking", is reflected in one's lack of "judgement", i.e., (in short) in one's speech being entirely constructed upon a "limited supply of stock phrases" (Arendt, 1971: 417). In listening to A. Eichmann's testimony, as she recalls it, the extreme phenomenon had "quite factual[ly]" and unexpectedly been imposed upon her (Arendt, 1971: 416). "Struck", as she found herself, by such "extraordinary shallowness" as the only enduring explanation of the deeds (Arendt, 1971: 416), she controversially and painfully spoke of "the banality of evil", this "phenomenon of evil deeds, committed on a gigantic scale, which could not be traced to any particularity of wickedness, pathology, or ideological conviction in the doer" (Arendt, 1971: 417). Notably, however, only in such an extreme case may we correctly speak of "the banality of evil". Indeed, as Arendt herself nuances, a relative "absence of thought" manifests itself daily - and advantageously - through "clichés, stock phrases, adherence to conventional, standardized codes of expression and conduct [that] have the socially recognized function of protecting us against reality, that is, against the claim on our thinking attention which all events and facts arouse by virtue of their existence. If we were responsive to this claim all the time, we would soon be exhausted; the difference in Eichmann was only that he clearly knew of no such claim at all." (Arendt, 1971: 418). In line with this nuanced approach to "thoughtlessness", we appropriate Arendt's notions as conceptual paragons - that is, as heuristic, illustrative concepts that tie to a rare and extreme, but nonetheless enlightening case - so as to gain insight into how a trend of "epistemological shortsightedness" may indeed characterize current sustainability research.
}

curtain" to alleviate the "invisibility of [LCA] practitioners' own values" remains a daunting task that is unlikely to be pursued (Freidberg, 2015). For Arendt, radical creativity stems from one's ability to "think without a bannister" (Yough-Bruehl, 2004: 453), that is (archetypally speaking), "without any preconceived system" (Arendt, 1973), such as that of institutional science's "truth" criterion:

After "thinking", you remain in a way, empty [...]. And once you are empty, then (in a way which is difficult to say) you are prepared to judge - that is, without having any book of rules under which you can subsume a particular case, you have got to say, "This is good," "This is bad," "This is right," "This is wrong," "This is beautiful," "This is ugly." [...] That is, we are now prepared to meet the phenomena, so to speak, head-on, without any preconceived system (Arendt, 1973: 011836).

"Thinking", as such, prepares one to "judge without a concept" (Zerilli, 2005: 173); in other words, it prepares "the creative discovery of relationships among appearances that have no logical connection" as "an exercise of radical imagination" (Zerilli, 2005: 173): hence, the pivotal potential of art, or science-fiction (SF) literature, to catalyze "thinking" about current sustainability crises. Although one may logically - and hence legitimately - argue that no "thought" or "imagination" emerges out of "nowhere", it must equally be recognized that "nowhere" always ends up being "somewhere" under critical socio-historical circumstances, such that "the necessity here is nothing but the possibility of impossibility" ${ }^{4}$ [Our own translation] (Barel, 1989: 155). In the end, all indeed seems to occur as if "[thinking]'s political and moral significance comes out only in those rare moments in history when "Things fall apart; the center cannot hold; /Mere anarchy is loosed upon the world," when "The best lack all conviction, while the worst/Are full of compassionate intensity." (Arendt, 1971: 445). Are we not, arguably, at the cusp of such a "rare moment" in history, when "thinking ceases [or, rather, ought to cease] to be a marginal affair in political matters [including matters of knowledge, which are far from a-political]" (Arendt, 1971: 445)?

Within the specific context of sustainability research - in which the criticality of issues at hand has long been acknowledged, and the need of "advancing sustainable solutions" have recently been seized as a breeding ground for "an interdisciplinary and collaborative agenda" (McCormick et al., 2016: 1) - Arendt's notion of "thoughtlessness" and its corresponding lack of imagination (or judgment) appears to hold a singular and untapped potential. As the focus of sustainability research tends to be relentlessly placed upon "problem-solving" - almost as if problem definition held no debate of its own or came without any political considerations -

\footnotetext{
4 "The possibility of the impossibility" evoked by Barel (1989) corresponds precisely to this possibility that "nowhere" becomes "somewhere" in the context of crisis. Hence the "misconceptions of social reproduction", which radically eliminate the paradoxical possibility that the social system auto-reproduces and heteroreproduces itself simultaneously: "le système reproduit est à la fois lui-même et autre chose que lui-même"(Barel, 1989: 141). Yet this impossibility must be made possible, such that there can be "revolution", "slow mutation" or "adaptation" [Our own translation] (Barel, 1989: 156). Yves Barel writes: "The paradox does not simply express an "intellectual antinomy": it is really, by struggling for its existence, its survival, by seeking to control all the internal and external perturbations that beset it, that a social system seeks to transcend itself, that is to say, to behave paradoxically, since what it endeavors is impossible and yet crucial: the necessity here is nothing but the possibility of impossibility. The impossibility emerges from theoretical analysis a posteriori." [Our own translation] (Barel, 1989: 155-156).

${ }^{5}$ Here, Arendt quotes a well-known piece by the Irish poet William Butler Yeats (1865-1939), “The Second Coming”, written in 1919, in the aftermath of World War
} I. 
"thoughtlessness" may usefully be transposed to the field, and acquainted with a kindred phenomenon of "epistemological shortsightedness". Such a predicament, however understandable, ultimately prevents crucial knowledge avenues from being explored and traveled (Nicolescu, 2014; Freidberg, 2015). In line with Susanne Freidberg (2015)'s recent appeal to the LCA community to "come out from behind the curtain", it is herein posited that current circumstances call for a joint effort by sustainability researchers to break away from such epistemological shortsightedness and flawed rigor.

The present paper contributes to this effort by conceiving of art, in general, and SF literature, in particular, as a knowledge type that is unbound by mere logical connections and that may be used as a catalyzer for "thinking" in spite of the relative invisibility of certain dilemmas.

One prime concern and powerful motive of sustainability research clearly is to foster a sustainable future for humanity: it might even be argued that it has become so obvious to researchers that it is no longer deemed necessary to voice it as such. Upon such a backdrop, cultivating "radical creativity" by opening a dialogue between SF literature - which also concerns itself with the future of humankind - and social research within the field of sustainability holds great promise. Such a dialogue may help researchers to "think without a bannister", hence unlocking new theorizing potentials that would have remained invisible under the exclusive (and restrictive) light of institutional science. Such creativity may contribute to reinventing products and services or to reshaping business models. It may be leveraged in the (re)design of organizations and economic models that better meet the ecological and social demands of SD. Ultimately, however, "radical creativity" is better suited for recasting part of sustainability research based on an increased epistemological pluralism. To the extent that SD issues affect society as a whole, problematizing firm and management theories through "radical creativity" indeed always partly amounts to problematizing the relationships between researchers, research, and society. As Heras and Tàbara (2014, p. 379) state, "Facing these global societal challenges will require rethinking the largely outdated ontologies, assumptions and epistemologies that we use to frame and guide mainstream goals and practices in science and education". In line with what has been thus far argued, the present work is specifically aligned with this larger societal perspective, and our aim is to explore the potential of SF literature to support social theory building.

In what follows, it is argued that imagination plays an important role in theory building because it sheds new light on reality. More specifically, in social research, radically different perspectives such as those based in SF literature - may transform institutionalized policies and actions that are problematic in light of social and environmental issues. However, these perspectives are rarely explored in regular theory building for numerous reasons (such as the evaluation process of scientific contribution). Some researchers have nonetheless turned to art to experiment with new ways of theorizing (e.g., Schmidt et al., 2015). In line with such initiatives, the present article shows that it can be fruitful to open the theorizing process to what may be considered new forms of knowledge. We then show how such an exercise can be applied to theories of the firm and their relationship to society.

Our argument is three-fold: first, we look at the contribution of non-scientific knowledge production from an epistemological perspective. Second, we explore the role of SF literature as a potential inspiration for theorizing about the business firm. SF is chosen because it mainly addresses radical futures by extrapolating the impact of actual, emerging and imaginary technologies as well as social evolution. Finally, we illustrate how the business firm is conceptualized within this literature and conclude by suggesting what may be learned from such work.

\section{Art, knowledge and theory}

The importance of creativity in theory building stems from the idea that solutions emerge from novel (or nonexistent) formulations of problems: "how problems are conceptualized will largely define the solutions sought" (Meppem, 2000, p. 48). Thus, the reorganization of a problem based on imagination and creativity is a valuable heuristic tactic.

Imagination is often successfully invited by putting together hitherto isolated items, by finding unsuspecting connections ... As you re-arrange a filing system, you often find that you are, as it were, loosening your imagination. (...) Of course, you will have in mind several problems on which you are actively working, but you also try to be passively receptive to unforeseen and unplanned linkages (Mills, 1959, p. 201, 212). Quoted in Forstater (2004, p. 28).

Indeed, it is necessary to formulate problems that are neglected - or rendered invisible - because they question those basic institutions upon which today's challenges are defined and conceptualized. Studies that build upon hypotheses involving drastic change might explore possible societies emerging from disruptive phenomena to open up a range of solutions.

Because of our cognitive biases, it is difficult to radically change our perspective on current issues, as so doing would involve breaking with social representations, i.e., a well-learned frame of analysis shared by people around us (Jodelet, 1989). However, by trying to view the world through a new lens, individuals may construct a different perspective. Innovators have had to address substantial resistance. Galileo could not convince people of today's acknowledged heliocentric solar system. In a techno-scientific society, the nature of resistance has changed, but many who suggest a novel outlook upon the world are considered dissonant or disruptive voices. Chartier tells of the anxiety felt by Bourdieu because of violent resistance to his analysis. He understands the event as follows: while providing a more lucid outlook upon phenomena, the researcher provokes a feeling of disillusionment, which is highly unwelcomed by people in general (Bourdieu and Chartier, 2010, p. 16-17).

In social research in particular, theoretical work begins by negating intuitive common sense, from which is built a perspective that reveals hidden features that can better explain a range of phenomena. As a foundational pillar of sociology, Durkheim proposed in 1894 that we let go of pre-notions as a basis for scientific endeavor. With regards to freeing ourselves from these pre-notions, he explains, the researcher should conceive of theoretical objects that place reality in a different light.

This theoretical work aims to liberate the researcher from social representations and to propose concepts emancipated from ideology or rationalization. However, even within disciplines, a certain orthodoxy that stifles problem definition and theoretical innovation may develop. Over the past few years, the crossing of disciplinary boundaries has frequently shaken a priori ideas and provided new opportunities in certain fields. For example, we should recall the recent developments in neuroscience, which revolutionized the postulates of several disciplines, beginning with economics. In a recent paper, Camerer et al. (2005) show that advances in neuroscience have invalidated certain assumptions upon which many fundamental economic models are built. The authors argue that radical renovation, nourished by interdisciplinary dialogue, is necessary. Following this path, new business models highlight the recent advances in neuroscience, such as the fact that 
decisions are the result of a combination of conscious and unconscious mechanisms rather than the outcome of explicit and linear control (Benhabib and Bisin, 2002; Bernheim and Rangel, 2004; Loewenstein and O'Donoghue, 2004).

The dialogue between disciplines can thus be a vector for theoretical renewal. However, interdisciplinarity and transdisciplinarity can also involve a dialogue with other disciplines understanding that disciplines is used here in a broad sense. In other words, researchers can nurture a fruitful dialogue not only with peers from other fields but also with non-scientific interlocutors. As Boutet (2010b) explains,

Despite its name, "transdisciplinarity" not only crosses disciplines, but also - which is more important - modes of knowledge. Indeed, it must be noted that if biology, physics and chemistry, for example, are distinct disciplines, they all relate to the same mode of knowing, the scientific knowledge. Psychoanalysis, art history and theology, which are rather distant fields from each other, all use the hermeneutic mode at some stage. Philosophy, which is itself sub-divided into different branches, is a mode of knowledge of a speculative or rational type. Accordingly, to fully understand the complexity, the dialogue between the modes of knowledge is equally, if not more, crucial than exchanges between disciplines. [Our own translation] (Boutet, 2010b, p. 1)

The radical transdisciplinarity advocated by Boutet (2010b) is based not only on the character of a fruitful dialogue between disciplines but also on the notion that knowledge is not exclusively scientific in nature (Boutet, 2010b). The scientific method can produce specific knowledge through objectification, but this is not the only possible form of knowledge: as Higgins (2003, p. 5) indicates " $(. .$.$) the scientific method used in the study of organiza-$ tions is not the only form of knowledge that can be utilized." [Our own translation]. Thus, knowledge derived from practice and discredited by a so-called scientific method founded upon its negation (Bachelard, 1970) is, in some new way, rehabilitated as a profane or folk knowledge that is useful to a broader approach to knowledge (Bangerter, 2008).

However, how can we integrate art into the theorization process? In 1970, Koestler wrote: "Einstein's space is no closer to reality than Van Gogh's sky. The glory of science is not in a truth more absolute than the truth of Bach or Tolstoy, but in the act of creation itself" (Koestler, 1970, p. 253).

Is art a genuine form of knowledge? For Todorov (1996), the scientist divides the whole into its constituent parts, whereas the artist proceeds by means of synthesis and seizes all in global intuition. However, in both instances, it is a question of knowledge, Todorov insists. It is, however, a different form of knowledge, explains (Boutet, 2010b), an "experiential" knowledge:

(...) rather than an objective knowledge, as that produced by scientific approaches, or rational knowledge as produced by the speculative approach of philosophy, art practice leads to experiential knowledge. Through his creative activity, the artist does not know things objectively and rationally, he knows them as we know that with which we have a relationship and he has deepened his knowledge by deepening this relationship [Our own translation] (Boutet, 2010a, p. 5).

As an illustration of this understanding, Bendor et al. (2015, p. 57): "see the arts as a way of knowing the world - a methodology for exploring, understanding, and building human realities".

However, if art can be conceived of as knowledge and some artistic approaches reflect a real work of research, it is far too rarely placed into dialogue with the scientific field likely to be nourished from it. Both the work [oeuvre] and (in exactly the same way) the research work from which it results typically remain estranged from the disciplines they might inspire (Boutet, 2010b). Although Jung used art for his research on the psyche, the work of Joseph Beuys, for example, remains a stranger to philosophy, just as the work of Bach is not studied in mystical theology (Boutet, 2010b).

(...) [If] the artist is interested in anything other than the art itself, if he is interested in situations or in existential, philosophical, political, consciousness (etc.) issues, specialists in these other issues (sociologists, psychologists, theologians, etc.) will only rarely be informed. (...) A long list of examples, taken both from history as well as from contemporary art, could $(. .$. highlight the relative invisibility of such research [Our own translation] (Boutet, 2010c, p. 3).

Nevertheless, a growing body of research proposes art as a fruitful and indeed necessary input to social science knowledge, as art is advocated to be a specific form of knowledge (Barone and Eisner, 2011; Leavy, 2008) and such an approach exploiting art to better understand and conceptualize sustainability issues has been used by several authors recently. For example, because "sustainability may imply a challenge to our underlying dominant cultural ideas about nature, science, technology, and society", Bendor et al. propose exploring public engagement on sustainability "through the lens of aesthetics - as a question of experience, affect, creativity, and self-reflection" (2015, p. 54).

These approaches [of hybridization between art and science] combine a more social-constructivist and interpretive understanding of knowledge and social dynamics - including the role of emotions, beliefs and aesthetics, with other empiricist and critical approaches. Such art-science triangulation allows us to unveil meanings, processes and structures that condition social action (Finley, 2008; Knowles and Cole, 2008; Sullivan, 2010). Arts-based research practices are, therefore, co-produced and applied within the intersections of multiple disciplines and methods (Heras and Tàbara, 2014, p. 381).

In line with this new trend in research and the necessity of opening boundaries when dealing with an issue as urgent and complex as sustainability, this paper builds on what a particular form of art, literature - SF writings - bring to social science. However, if art has been employed in different phases of research, such as data collection, analysis or representation to "convey meanings that could be otherwise unavailable" (Heras and Tàbara, 2014, p. 381), we argue in this paper that art can be at the heart of a renewed and innovative theorization process.

\section{Literature as a source of inspiration for the social sciences}

From a general point of view, the social sciences often suffer from a lack of new theoretical approaches (Barrère and Martuccelli, 2009). Therefore, they continue to refer to conventional assumptions, whereas an understanding of today's phenomena requires questions to be raised about realities that are difficult to imagine and forecast. Along the same line of thinking, Higgins (2003, p. 8) notes that " $(. .$.$) current fads in organization theory (OT) such as$ knowledge management, reveal the limitations of thinking through the human/technological dualism, hence they question the suitability and sustainability of humanism in a technologically driven age." 
With regard to sustainability challenges and globalization, the social sciences in general and sociology in particular are barely able to propose new theories and new hypotheses, sometimes for fear of falling into models considered idealist or naturalistic (Lever-Tracy, 2008).

This context does not suggest that the social sciences in themselves are deficient, whether through an excess of empiricism or theorizing, as Mills (1959) would suggest. It is more likely that the changes that must be explored are not congruent with current systems: the shift to sustainability involves multiple and difficult disruptions.

Following Barrère and Martuccelli (2009), if social sciences struggle to produce what is expected of them, the cause is more likely the absence of imagination than the absence of science. Such circumstances lead to conservatism in the representation of the world and of social actors such that several theories appear out of sync in relation to the transformations impelled by the ecological crisis. These authors believe that the ignorance of recent artistic developments is not alien to the difficulty of the social sciences to ask new questions and to create new opportunities. This ignorance would explain, in part, why these disciplines remain mired in an obsolescent representation of people and society (Barrère and Martuccelli, 2009, p. 12). In the authors' eyes, literature could nourish social theorizing and open a highly stimulating hermeneutical universe. Similar to the researchers discussed below, Barrère and Martuccelli (2009) believe that literature, particularly in its more modern forms, offers a specific knowledge that is capable of enriching thinking and sociological analysis. A dialogue between the social sciences and literature would, therefore, foster fruitful exchanges between scientific concepts and categories, joints and interpretations that are notably inspired by the manifold possible interpretations of literary work. As Eco explains, "artwork is a fundamentally ambiguous message, a plurality of meanings that coexist in a single meaning" (Eco, 1965, p. 12). This freedom of appropriation is unique to every work of art as its underlying condition.

The exercise proposed by Barrère and Martuccelli (2009) assumes a certain type of reading in an approach they refer to as the hermeneutics of invention. The literature explores the social world with freedom and makes assumptions that may seem frivolous but correspond, in fact, to thought experiments (Gendler, 1998). It is precisely this extra imagination that the social sciences researcher can exploit, first by identifying the novel propositions it contains and then by transforming them into theoretical hypotheses through this hermeneutics of invention.

The hermeneutics of invention is primarily based on the notion that there is a literary knowledge that is irreducible to other thinking and representation systems (Barrère and Martuccelli, 2009, p. 50). It is possible to access this knowledge insofar as one recognizes its specificity; it is then possible to exploit it from a theorizing perspective. As Barrère and Martuccelli (2009) explain, the exercise does not necessarily involve searching works of literature for a scientific hypothesis or a sociological theory, even when that is possible. Instead, the notion is to identify emerging specific knowledge that does not coincide with analytical frameworks and theories already formalized. This is not simply a question of striving to find in literary work reflections about our social reality but instead to discover tools for the researcher to renew his or her understanding and interpretation of society. Finally, the hermeneutics of invention does not imply that theoretical concepts can be directly extracted from novels or other literary works. The researcher must undertake a translation exercise through which knowledge contained in the artistic work is reformulated in light of the specific interests of the social science theorization process. In short, the hermeneutics of invention initially requires the existence of a literary knowledge that is different but relevant to the social sciences. The approach postulates the otherness between literary and sociological knowledge based on which a dialogue can be fruitful; these different types of knowledge cannot be confused with one another, but they also do not completely break away from one another. The hermeneutics of invention does not involve establishing a correspondence between a social context and an artistic work to propose an interpretation; instead, it involves using artwork to generate new categories of sociological analysis. The hermeneutics of invention considers literary knowledge as a stimulus for theoretical imagination. This practice requires going back and forth continuously between strict interpretation and invention, understanding that "truth" so obtained should be judged with respect to its analytical openness and the capacity to renew the concepts and sociological categories that it has engendered (Barrère and Martuccelli, 2009, p. 355-356).

Considering the entire literature corpus, SF does not appear to be a clearly relevant choice for conducting such hermeneutics of invention. Nonetheless, if we are to study the changes introduced into our societies given the ecological crisis, this literature at once becomes particularly interesting, given that many SF stories occur in post-ecological contexts. ${ }^{6}$ SF writings and movies have already been analyzed by several scholars around the world, including by sociologists, anthropologists, and even historians (Gyger, 2002; Moylan and Baccolini, 2003; Hassler and Wilcox, 2008). These works provide different accounts demonstrating the potential of SF in scientific research, first by imagining and illustrating social changes. However, only a few authors recognize the heuristic potential of SF more explicitly (Gyger, 2002; Rumpala, 2010; Costanza, 2000). One of these scholars, Costanza, explains as follows:

The best SF is an exercise in envisioning. By placing the fictional narrative in the future, one can explore a range of core issues of critical concern to the present, and also paint a rich, multicolored picture of a world to which we can aspire (or one we wish to avoid) (Costanza, 2000, p. 167).

Costanza has explored the envisioning potential of SF using literature from a variety of authors to illustrate possible futures (Costanza, 1999, 2000). In this case, SF is used as a tool for envisioning; the narratives facilitate formalizing different visions of the future upon which a dialogue can begin. However, SF can more directly be viewed as a creative process that proposes a hypothesis for further reflection and to deepen the understanding of how societies produce themselves (Touraine, 1977). SF is a work of fiction with a hypothesis that is similar to the experimental novel defined by Emile Zola as a tool for investigation. Thus, SF tries, by experimentation, to understand the mechanisms regulating social behaviors and social structuration (Gyger, 2002, p. 14-15).

Contrary to what one might believe, SF writing is far from involving a simple and profane knowledge. As Klein (1995) writes playfully, "Science Fiction and Future Studies are half-sisters with a common father, the desire to understand the future, and for mothers just two distant cousins, imagination and method." He adds that "[a] science-fiction writing is frequently the result of the meeting in the same man of an exceptional writer and a researcher" [Our own translation] (Klein, 1995, p. 7). Similarly, since the late 1960s, Nisbet (1968, p. 60) indicates that "[i]t is now common practice for some thinkers, ranging from academics engaged in philosophical speculation about the nature of the future to

\footnotetext{
${ }^{6}$ As explained in Gendron and Audet (2016), the concept of post-ecological society refers to societies where the degradation of ecosystems have reached a point of no return.
} 
professional futurologists, to argue that SF is a valuable adjunct to future studies." Hollinger highlights that SF studies “(...) [have] achieved some legitimacy within academia (...) [and that] sciencefiction studies [are] flourishing as never before, even as efforts to define what SF is/is becoming are being challenged as never before" (Hollinger, 1999, p. 262).

Gerlach and Hamilton (2003) divide researchers into three categories: those who think that SF writings define a distinguished genre of literature, those who think that SF has become a way of thinking and knowing, and finally, those who employ SF writings to analyze social situations and contexts.

In our view, the heuristic potential of SF involves its ability to nourish new hypotheses upon which social theory is developed and to stimulate sociological imagination to free it from accepted knowledge. In this sense, science fiction can be part of a fruitful knowledge production process (Rumpala, 2010, p. 98). This experimentation process is made possible by the "what if..." technique and enables the questioning of what seems obvious (Rumpala, 2010, p. 103), i.e., to think what has remained unthought, which is the very task of the social scientist (Lenoir, 1999, p. 99).

Although the target of SF is the future, this future is relative to the writing period. Hence, in the 1950s, SF primarily addressed the risks of a nuclear apocalypse; from 1960 to 1970, it involved inciting individuals to dream of space exploration; from 1980 to 1990 , it tried to stimulate the imagination of the masses in the face of the arrival of information and communication technologies; and more recently, it is increasingly addressing topics of global warming and/ or the environmental crisis more generally (Michaud, 2012).

According to Smith et al. (2003), since at least the middle of the last century, researchers have been taking the role of SF into account in their work. For example, these authors note that the US Army Armament Research Development and Engineering Center invited an SF writer to contribute to the Force XXI future weaponry program. Similarly, DARPA brought together scientists, technologists and futurists to introduce new ideas, and the US government enlisted SF writers as advisors in the field of non-lethal weaponry.

The heuristic method, as with other assumptions mobilized by the genre, is divided into four stages: the description of an imaginary situation; abductive reasoning, whose objective is to emphasize what, in our reality, makes a given future possible (whether it is about history or the present); deductive reasoning, which provides an analysis describing the possible impact of the imagined situation at the political, demographic, or ethical level; and finally, political thinking, which involves the process of making explicit what would need to be undertaken to prevent (or encourage) the consequences, depending on whether these consequences are positive or negative.

\section{SF and enterprise theory}

As Germain (2012, p. 15) reminds us: "Never before (...) has the organization been the subject of so many works of literary fiction television or film, oscillating between dramatic critics and irony." He adds that " $[t]$ hese representations are not to be underestimated in their anthropological dimension insofar as they emphasize the organization's traits that no research will be able to display" [Our own translation] (Germain, 2012, p. 15). Some researchers have already understood this reasoning and have begun to mobilize fiction in their analysis. For example, Holt and Zundel (2014) are inspired by The Wire ${ }^{7}$ series to consider several management phenomena in an article entitled "Understanding Management, Trade, and Society Through Fiction: Lessons from The Wire."

\footnotetext{
7 The Wire, produced by Blown Deadline Productions and Home Box Office,
} 2002-2008.
We decided to explore SF as a genre to determine how it represents the enterprise. The choice of this popular genre is deliberate because SF's mission is frequently to explore upheaval scenarios that social scientists are struggling to model, a limitation that is denounced by commentators. For example, Spiegel talks about the novel Oryx and Crake as "[p]ossessing the imagination and insight that international relations theorists lack. Atwood's rendition highlights the potential implications of a neomedieval world that have been overlooked by theorists" (Spiegel, 2010, p. 15).

\subsection{The company in $S F$}

SF does not neglect the business world. In fact, SF is replete with descriptions of life in a factory, a laboratory, etc. Often, evil multinationals rule the world, based on the information they control. SF explores different forms of business, whether network enterprises, virtual or automated enterprises that are sometimes populated by robots workers, slaves or political prisoners. Although they are hypothetical companies, SF descriptions of organizations freely borrow features examined by the management literature (rationality, automation, primacy of effectiveness, etc.). However, they also objectively provide ways of thinking about developing the company as a social institution. Regarding SF objectivity, Klein (1995, p. 8) explains that “(...) when [SF writers] undertake to elucidate the strategic horizon of a company or industry, they adopt information and reflection frames that do not belong to them and have a certain degree of objectivity." [Our own translation].

Indeed, SF writers frequently use highly qualified scholars and experts in the field regarding their topics of interest. These people extract and filter all relevant scientific information, particularly from scholarly databases. In parallel, writers rely on a team of experts that are both upstream and downstream of their writings. Thus, in addition to their geniality, SF writers have access to advanced research methodologies and outcomes.

Modern SF generally depicts the firm as the central element of a future overcome with technology and corruption. Since the 1980s, the cyberpunk movement in particular has developed the concept of mega-corporations, free from government or even citizenry control, while exercising political power that is far more intrusive than might have ever been previously imagined thanks to biotech and communication technologies. ${ }^{8}$ As highlighted by Hollingen, " $[\mathrm{t}]$ he widespread attention which cyberpunk attracted from outside the SF has been one important factor in its growing prominence as an object of study in a variety of disciplines" (Hollinger, 1999, p. 262).

The cyberpunk literary movement was first inspired by Philip K. Dick, who in the early 1950s explored the possible features of a future dominated by corporations. In his short story "Paycheck" written on July 31, 1952, and first published in the June 1953 issue of Imagination, Dick depicted the corporation as a sanctuary, offering protection from the law of the State.

Although an individual person was defenseless, a business was not. The large economic forces had managed to remain free, although virtually everything else had been absorbed by the Government. Laws that had stopped protecting private persons still protected property and industry. The SP [Security Police] could pick up any given person, but they could not enter and seize a company, a business. That had been clearly established in the middle of the twentieth century. Business, industry, corporations, were safe from the Security Police. Due process was

\footnotetext{
${ }^{8}$ See, for example, Neuromancer by William Gibson or Ghost in the Shell by
} Masamune Shirow. 
required. Rethrick Construction was a target of SP interest, but they could do nothing until some statute was violated. If he could get back to the Company, get inside its doors, he would be safe. (...). The modern church, sanctuary. It was the Government against the corporation, rather than the State against the Church. The new Notre Dame of the world. Where the law could not follow. (Dick, 2004, p. 229).

The assumption of the sanctuary company is declined in three related concepts:

1. The sanctuary, originally the holy place in which the police, justice, and the army cannot intervene without having received prior authorization, was extended to churches, universities and places in which justice is made and given, e.g., Parliament and the Palace of Justice.

2. Immunity allows for an escape from prosecution by virtue of a company's status or of the actions of its function (political leaders, diplomats and other foreign representatives of a State).

3. Asylum refers to the possibility of being exempt from prosecution or from the application of justice, the police or an opposing army.

The company, as formulated by Dick, is a sanctuary company because it can avoid ordinary laws and is likely to serve as an asylum for employees and executive officers; the main character of the book takes refuge in the company because the police cannot pursue the company. If this assumption seems absurd, it is not without echoes in reality. For example, the liability cap enacted in 1990 after the Exxon Valdez oil spill in the USA limited damages to companies in cases of ecological disaster. The Safe Harbor Act of 1995 enacted in the USA protects companies from shareholder lawsuits for misleading forecasts of their activities. Finally, the prohibition of boycotts in France (2009) kept companies safe from harm caused by negative civil campaigns. On several occasions, large companies have avoided actions associated with damages, even when proven true, and they have safeguards from citizen actions and from consumer prosecutions. These safeguards often reserve an exempted status for large companies, establishing sanctuaries and providing virtual immunity to their leaders. In return, companies develop their own system of regulation and justice as an offshoot of their social responsibility programs.

The corporation imagined by Dick is generally opposed to the State and stands as a different power fighting for expanding its control. In the cyberpunk movement that was later constructed on Dick's earlier work, the corporation becomes a "megacorporation", a conglomerate benefiting from a monopoly as powerful as or more powerful than states. Run by privileged senior executives with no moral sense, the corporation has its own laws and rules and its own vast territories; moreover, it is in complete control of its employees. ${ }^{9}$ In numerous aspects, corporations act as a government. These features make the corporations resemble those of early capitalism, such as the Dutch East India Company, that exercised numerous sovereign powers, such as ensuring justice, issuing money, and even conquering territories (McLean, 2004). In these representations, corporations are not fighting against the State as they do in Dick's works; instead, they stand as a type of "private state" in a stateless world. As Kain explains:

"[a] book like Neuromancer basically takes it for granted that the future is pretty stateless, governed instead by an ad hoc system

\footnotetext{
${ }^{9}$ For an example of the fight between a hacker and corporation, see Burning chrome by William Gibson (1986).
}

of corporate behemoths and an international regulatory agency, all built on the stilts of artificial intelligence" (Kain, 2011).

Prototypical of this hypothesis, Margaret Atwood's novels Oryx and Crake (Atwood, 2004) and The Year of the Flood (Atwood, 2009) envision a government controlled by corporations, a corpocracy, to use Appleton's terminology (Appleton, 2011). The works present a world that has " $[\ldots]$ degenerated into a greed-riddled, corporately controlled environment with rules being enforced by a corporate paid 'police force': the CorpSECorps" (Appleton, 2011, p. 66). As Atwood explains, in the world depicted in the novel, "there isn't any what you may call 'government' anymore. That's completely caved $[\ldots]$. [E]verything is being run by corporations now" (Atwood, 2009), a power enforced by the private police, the CorpSEcorps.

Their job is not only to protect the corporations and compounds from sabotage from other companies, other countries, various factions and plotters but also to maintain their unfair share of the marketplace (Atwood, 2004, p. 27). Atwood provides detailed information about the CorpSECorps, which "started as a private security firm for the Corporations, but then they'd taken over when the local police forces collapsed for lack of funding, and the people liked that at first because the corporation paid, but now CorpSECorps were sending their tentacles everywhere" (Atwood, 2009, p. 30).

In the cyberpunk literature, the firm is the primary vector of social inclusion, providing different degrees of participation. In the film Total Recall (2012), based on Dick's 1966 short story "We Can Remember It for You Wholesale", blue-collar workers live in a colony that is highly disadvantaged compared with the privileged United Federation of Britain territory. The firm acts as a powerful class division tool, following much of the SF literature: there is a clear delimitation between citizens based on their status in the corporation. As Spiegel argues, "by [...] commodifying art, disempowering the masses, or exacerbating class division, the transnational corporations that drive global integration bear significant responsibility for the social, cultural, political, and economic fragmentation" (Spiegel, 2010, p. 125).

Moreover, the class division is generally reflected geographically, as shown in Dick's and in Atwoods' novels. In Atwoods' novels, "[...] a select few, mostly bioengineers whose works constitute the backbone of corporate profit are barricaded into the armed and fortified corporate compounds (fortress, really)" (Appleton, 2011, p. 67). An antique medieval castle, "[...] the RejoovenEsense Compound has a wall twenty-seven feet high, with a six-foot wide rampart and slits every ten feet meant for observation but useful too for the emplacement of last ditch weaponry" (279) (Spiegel, 2010, p. 122).

In the novel, the territory is divided between pleeblands, controlled by the private police and street gangs, and wellprotected compounds. The compounds serve as the seat of power as well as a type of exaggerated gated community built by transnational corporations to seal off their upper and mid-level employees from the chaos and unpredictability (and profanity) of urban life in the pleeblands (Spiegel, 2010, p. 122).

Higgins (2003, p. 5) provides other examples of SF writings addressing organizations and ways of organizing, such as the role of humans within organizations (e.g., the films Rollerball (1975) and 1984 (1984)), the darker side of governments and commerce (The XFiles (1998), Aliens (1986) and Robocop (1987)), the influence of media on public perceptions of reality (The Running Man (1987), Videodrome (1983) and eXistenZ (1999)), and technology and human value (Matrix (1999)).

The firm can also stand as an alienating structure for compulsive consumers portrayed as diminished individuals - perhaps even 
more diminished than workers who stood as the main victims of firms in earlier SF works, such as Fritz Lang's Metropolis, released in 1927.

As they are currently portrayed in SF, the firm and its economic system admittedly seem far from what is most commonly put forward by management sciences as an organization's efficient rationalization process or outcome. Instead, SF cyberpunk narratives tend to insist on big company space as designed exclusively for and attainable by only a privileged few. As one of its focal points, tools and ladders of privilege are depicted, whereas these are rarely portrayed in traditional analyses of the firm.

Unlike other totalitarian worlds, such as Orwell's 1984 or Atwood's The Handmaid's Tale, corporations "go for gold" and control competition that could hamper corporate profits " $(. .$.$) the$ CorpSECorps 'police' eliminates any competition to corporate profits; it is, apparently, against the law to engage in free enterprise" (Appleton, 2011, p. 70). Nonetheless, the police openly avoid destroying oppositional social movements because the brandname corporations hiring this private police want "to be perceived as honest and trustworthy, friendly as daisies, guileless as bunnies" (Appleton, 2011, p. 70). However, as Appleton puts it,

(...) the so-called Capitalism prevalent in Oryx and Crake and The Year of the Flood is manipulative at best, totalitarian at worst. Instead of relying on supply and demand, the corporations have created artificial demands and promoted engineered dependencies. Manufactured diseases necessitate manufactured cures; body enhancements need to be maintained with age. Prices can be raised with ensuing procedures and by depleting natural resources, thereby ensuring ever-increasing consumer costs as the resources dwindle (Appleton, 2011, p. 70).

Radical scenarios such as those discussed immediately above are rarely taken into account when researchers propose theoretical models of ecological modernization or envision the potential of future public policies regarding sustainability. As argued herein, mainstream theorizing processes in accordance with the canons of management science and firm theories prevent current sustainability research from unlocking the value of such disruptive thought experiments. Nonetheless, if the current environmental crisis is to be fundamentally - that is, radically - approached, the potential relevance of previously untraveled research paths must be acknowledged and exploited. As such, today's SF narratives may (in whole or in part) be construed as powerful heuristics for present research. By postulating that SF's futuristic scenery and scenarios retain the potential to illuminate an understanding of the present from which they stem, one may indeed foresee novel problem constructs, open up otherwise unimaginable knowledge production avenues, and lay the groundwork for transdisciplinary solutions to such problems. Such novel problem constructs may, for example, inquire into how far we stand today, within specific social contexts, from a situation in which corporations have come to be immune to the law - in a manner similar to yesterday's churches or universities - or into what may ensue if companies were to replace states in a stateless world.

As explained by Appleton, "[ The Handmaid's Tale] novel is a speculation into the consequences of a power unchecked and (...) an economic system that is manipulated by the powerful" (Appleton, 2011, p. 66). For this reason, Margaret Atwood portrays her work as speculative fiction instead of as SF.

The ideas she formulates are not "pure fantasy, but rather [a] distinct possibility” (Appleton, 2011, p. 66). Commentators such as Kain (2011) clearly claim that SF explores conceivable future scenarios to become aware of unforeseen potentialities:
If anything, I'd like science fiction to deal with how the corporations of the future - if they are truly state-like and as bad as they're often presented - actually got to be so bad and so powerful. How, in other words, they become more like for-profit governments. In my hypothetical sci-fi film I'd use the corporate charter city as the backdrop. Maybe place it in some future dystopian state and then show how the charter city creates not only new freedoms and exit from the bad state, but other problems as well - perhaps with wealth inequality, for instance. You could take this any number of directions, and delve into issues of privacy, security, and so forth. I'm no fan of corporatism myself, obviously, but I don't see the problems undergirding corporatism quite the same as many of my progressive friends. And I think it would be interesting to deal with the question not simply in a negative light. Give me complexity in the political and economic systems present in my science fiction, not just in the technology. Everything is a trade-off. Science fiction should ask us what we're willing to trade, and at what price (Kain, 2011).

However, from the literature we have analyzed, we already see that certain issues are stressed, and we can draw theoretical insights. Cyberpunk literature makes it clear that the economic role of the corporation has been superseded by the social implications of its power; novels in this genre even depict a clear political role for the firm. As shown in Spiegel's analysis of Atwood's novel Oryx and Crake, the firm is shown as the central institution of a new political order in which sovereignty is fragmented among multiple levels of decision making. Neomedievalism is "a system of overlapping authorities and crisscrossing loyalties that hold all people together in a universal society" (Bull, 1977, p.246). Spiegel further describes as follows:

(...) a world of simultaneous globalization and fragmentation where the nation state persists, though weakened. Such a world resembles that of Western Christendom during the Middle Ages, when the universalism of the Catholic Church coexisted with the fragmentation of kingdoms into fiefdoms. With decentralized power and competing jurisdictions, the neomedieval "state" shares authority with regional and global entities above, and with sub-state and sub-national entities below, just as feudal lords shared authority with provincial officials above and vassals below. Without a strong, centralized state, nationality would no longer represent one's primary means of identification. Instead, loyalty would disperse among various local groups or transnational organizations, just as loyalty was spread between bonds of blood (kinship) and those of oath (vassalage) (Bloch 124). (Spiegel, 2010, p. 120-121).

For Spiegel, Atwood's novels clearly demonstrate the advantages of the neomedievalism concept over the "Three Worlds" model of globalization set forth in modernization theory (Holsinger, 59) (Spiegel, 2010, p. 121). From this perspective,

The division between the Compounds and the pleeblands exemplifies the seemingly paradoxical dynamics of integration and fragmentation and nation-centrism which Joerg Friedrichs terms the "triple dilemma of international relations theory" (477). Where IR specialists tend to treat these discourses as mutually exclusive, Friedrichs proposes that each plays a role in the reality of "simultaneous globalization and fragmentation in a world of nationstates" (479) (Spiegel, 2010, p. 123).

Globally, corporations and states are more alike than they are 
generally presented in contemporary discourse, representing vehicles of power for the privileged elite but with distinct justification and legitimation processes. Additionally, in light of how states are depicted in Orwell's 1984, corporations can exert total control over citizens, thanks to technology. However, instead of relying on adherence to a political (religious/dogmatic) line of thinking, the corporation is anchored in superficial desires (Atwood). Indeed, the corporation is more than the political actor that recent CSR literature proposes (Matten and Moon, 2013); it is a political structure because it contributes to and defines class division. Moreover, the economy no longer resides in some disconnected and apolitical sphere, i.e., the arena of private freedom apart from the State that controls certain aspects of life. Instead, the economy is a tool for political power, not only in terms of structuring society but also in terms of the very control of people's intimacy due to consumption and the logic of desire. In this sense, SF rehabilitates Braudel's conceptualization of capitalism over Smith's and voices class division instead of the ideology of the American dream. Although the firm is frequently confused with the market and even tends to disappear in economic ideology when reduced to the intersection of supply and demand curves, SF positions it as a central pole of power in a new geopolitical system. This preeminent role for the firm may be considered more deeply when formulating sustainability public policies and tools. Similarly, the social dimension of sustainability should more directly challenge decisions and processes among economic actors considering their impact on social stratification.

\section{Conclusions}

In conclusion, this paper addresses the opportunity to use art to experiment with new methods of theory building in the social sciences. In so doing, the paper mainly focuses on SF literature.

The extant literature indicates that the social sciences require new theoretical approaches to theorizing that address the complexity of today's world but also that tackle the discontinuity of social economic patterns caused by the global-scale ecological crisis.

This paper explores unusual knowledge sources, such as art, to provide new perspectives for thinking in the social sciences and to enrich the associated theorization process. This paper argues that art can be viewed as another form of knowledge although it may not correspond to traditional scientific processes of knowledge building. It also shows that art offers an experiential knowledge that is more comprehensive, intuitive, singular and sensorial than scientific knowledge. More specifically, literary art can provide a fruitful perspective for certain phenomena through this experiential knowledge but also by providing thought experiments. Furthermore, following the methodology of the hermeneutics of invention, which exploits literature for social science theorizing, this paper investigates the SF literature to envision the possible evolution of firms in post-ecological society.

The paper argues that SF emancipates thoughts from traditional realistic visions of the future, thus allowing for the exploration of non-linear phenomena. More generally, SF might become a social science methodology that allows management theories to be constructed from a completely different perspective, particularly with regard to such a challenging field as sustainable development.

Unlike traditional theoretical approaches, SF amplifies the political dimension of firms. In the cyberpunk movement in particular, firms become mega-corporations acting as private governments. These mega-corporations become spaces in themselves, serving as tools of social organization and structuring. They help create new geographies with protected zones in which privileged collaborators work at the corporations' headquarters and non-protected zones in which the non-privileged work. These dimensions are not taken sufficiently into account by the scientific literature and therefore must be considered by researchers not as fatalistic predictions but as possible future dimensions to understand and manage. Such an alternative point of view is not only useful but also necessary to build efficient sustainability public policies.

Finally, this research illustrates the potential of literature to enrich the "toolbox" not only of the manager but also of those who want to understand society from a different perspective. The multitude of assumptions contained in SF writings should convince avid researchers to renew and revise their theoretical approaches to draw on this unusual corpus. Given these challenges - but also the disruptive situations ahead - theoretical work must emancipate itself from orthodoxy and shake up preconceived and conventional ideas. From this perspective, the dialogue between art and theory appears not only fruitful but also necessary. Using SF literature as inspiration for social theorization involves not only thinking about the future but also envisioning it.

\section{References}

Appleton, S.A., 2011. Corp(Se)ocracy: marketing death in Margaret Atwood's Oryx and Crake and the year of the flood. Latch J. Study Lit. Artifacts Theory Cult. Hist. 4, 63-73.

Arendt, H., 1971. Thinking and moral considerations: a lecture. Soc. Res. 38 (3), $417-446$.

Arendt, H., 1973. Transcript of a Conference Given to American Society of Christian Ethics on January 21, 1973. Library of Congress.

Atwood, M., 2004. Oryx and Crake. Anchor.

Atwood, M., 2009. The Year of the Flood. Anchor.

Bachelard, G., 1970. La formation de l'esprit scientifique, vol. 11. Vrin Paris.

Bangerter, A., 2008. La différence des croyances populaires: Le cas de l'effet Mozart (Unlike popular beliefs: The case of the Mozart effect). Presses Universitaires de Grenoble.

Barel, Y., 1989. Le Paradoxe et le système : essai sur le fantastique social. Réédition de la version augmentée (2ème édition). Presses universitaire de Grenoble.

Barone, T., Eisner, W.E., 2011. Arts Based Research. Sage Publications.

Barrère, A., Martuccelli, D., 2009. The novel as laboratory: from the literary knowledge to sociological imagination. Le roman comme laboratoire: de la connaissance littéraire à l'imagination sociologique, vol. 1153. France.

Bendor, R., Anacleto, J., Facey, D., Fels, S., Herron, T., Maggs, D., ..., Sheppard, S., 2015. Sustainability in an imaginary world. Interactions 22 (5), 54-57.

Benhabib, J., Bisin, A., 2002. Self-control and Consumption-savings Decisions: Cognitive Perspectives. New York University, New York.

Bernheim, B.D., Rangel, A., 2004. Addiction and cue-triggered decision processes. Am. Econ. Rev. 94 (5), 1558-1590.

Bourdieu, P., Chartier, R., 2010. Le sociologue et l'historien, préface de Roger Chartier (Sociologist and historian: foreword by Roger Chartier). Agone, Marseille-Paris.

Boutet, D., 2010a. Art, connaissance et transdisciplinarité : quelques idées (Art, knowledge and trasdisciplinarity : some ideas). http://www.recitsdartistes.org/ documents/textes-theoriques/0/4_3-art-connaissance-et-transdisciplinarite. pdf (Accessed 31 May 2016).

Boutet, D., 2010b. La pratique créatrice comme voie de connaissance : art et recherche spirituelle (Creative practice as a way of knowledge: Arts and spiritual research). In: Proc. Colloque Approches transdisciplinaires de la spiritualité dans les arts et les sciences. Université de Nice, France, 9-10 June, 2011.

Boutet, D., 2010c. L'art comme mode de recherche et de connaissance (Art as a mean of research and knowledge). http://www.recitsdartistes.org/documents/ textes-theoriques/0/1_1-1-art-comme-mode-de-recherche-et-de-connaissance. pdf (Accessed 31 May 2016).

Bull, H. 1977. The Anarchical Society: a Study of Order in World Politics. Macmillan.

Camerer, C, Loewenstein, G. Prelec, D., 2005. Neuroeconomics: how neuroscience can inform economics. J. Econ. Lit. 43 (1), 9-64.

Costanza, R., 1999. Will it be star trek, ecotopia, big government, or mad max? The Futurist 33 (2), 23.

Costanza, R., 2000. Visions of alternative (unpredictable) futures and their use in policy analysis. Conserv. Ecol. 4 (1), 5.

de Haes, H.U., Jolliet, O., 1999. How does iso/dis 14042 on life cycle impact assessment accommodate current best available practice? Int. J. Life Cycle Assess. 4 (2), 75-80.

De Schryver, A., Humbert, S., Huijbregts, M.J., 2013. The influence of value choices in life cycle impact assessment of stressors causing human health damage. Int. J. Life Cycle Assess. 18 (3), 698-706.

Dick, P.K., 2004. Paycheck. Gollancz, Kindle format, London.

Eco, U., 1965. L'œuvre Ouverte (The Open work). Editions du Seuil, Paris.

Finkbeiner, M., Ackermann, R., Bach, V., Berger, M., Brankatschk, G., Chang, Y.-J., Wolf, K., 2014. Challenges in life cycle assessment: an overview of current gaps and research needs. In: Klöpffer, W. (Ed.), Background and Future Prospects in 
Life Cycle Assessment. Springer, pp. 207-258.

Finley, S., 2008. Arts-based research. In: Knowles, J.G., Cole, A.L. (Eds.), Handbook of the arts in qualitative research: perspective, methodologies, example and issues. Sage Publications, Thousand Oaks.

Forstater, M., 2004. Visions and scenarios: Heilbroner's worldly philosophy, lowe's political economics, and the methodology of ecological economics. Ecol. Econ. 51 (1), 17-30.

Freidberg, S., 2014. It's complicated: corporate sustainability and the uneasiness of life cycle assessment. Sci. Cult. 24 (2), 157-182.

Freidberg, S., 2015. From behind the curtain: talking about values in LCA. Int. J. Life Cycle Assess. 1-5.

Funtowicz, S.O., Ravetz, J.R., 1993. Science for the post-normal age. Futures 25 (7), $739-755$.

Gendler, T.S., 1998. Galileo and the indispensability of scientific thought experiment. Br. J. Philos. Sci. 49 (3), 397-424.

Gendron, C., Audet, R., 2016. L'environnement au prisme de la science-fiction. De la dystopie à la reconstruction du rapport Homme-Nature dans les sociétés postécologiques. Futuribles, Juillet-Aout 2016, pp. 73-84. No 413.

Gerlach, N., Hamilton, S.N., 2003. Introduction: a history of social science fiction. Sci. Fiction Stud. 30 (2), 161-173.

Germain, O., 2012. Introduction. Comme il vous plaira (As you like). In: Germain, O. (Ed.), Les grands inspirateurs de la Théorie des organisations [The great inspirers of Organization Theory]. Tome 1. HEC Montréal; Université Paris Dauphine.

Gibson, William, 1986. Burning Chrome. Grafton Books, London.

Gyger, P.J., 2002. Pavé de bonnes intentions : détournement d'utopies et pensée politique dans la science-fiction (Paved with good intentions: diversion of utopias and political thought in science-fiction). In: Haver, G., Gyger, P.J. (Eds.), De beaux Lendemains? Histoire, société et politique dans la science-fiction. Éditions Antipodes.

Hassler, D.M., Wilcox, C., 2008. New Boundaries in Political Science Fiction. Univ of South Carolina Press.

Heiskanen, E., 1997. The social shaping of a technique for environmental assessment. Sci. Stud. 11 (1), 27-51.

Heiskanen, E., 2002. The institutional logic of life cycle thinking. J. Clean. Prod. 10 (5), 427-437.

Heras, M., Tàbara, J.D., 2014. Let's play transformations! Performative methods for sustainability. Sustain. Sci. 9 (3), 379-398.

Hertwich, E.G., Hammitt, J.K., Pease, W.S., 2000. A theoretical foundation for lifecycle assessment. J. Ind. Ecol. 4 (1), 13-28.

Higgins, M., 2003. Introduction. more amazing tales. In: Smith, W., Higgins, M., Parker, M., Lightfoot, G. (Eds.), Science Fiction and Organization. Routledge, London and New York.

Hollinger, V., 1999. Contemporary trends in science fiction criticism, 1980-1999. Sci. Fiction Stud. 26 (2), 232-262.

Holt, R., Zundel, M., 2014. Understanding management, trade, and society through fiction: Lessons from the wire. Acad. Manag. Rev. 39 (4), 576-585.

Jantsch, E., 1972. Towards interdisciplinarity and transdisciplinarity in education and innovation. In: Interdisciplinarity: Problems of Teaching and Research in Universities. OECD, pp. 97-121.

Jodelet, D., 1989. Les Représentations Sociales. PUF, Paris.

Kain, E., 2011. Ridley Scott's 'prometheus' and the Science Fiction of Corporatism. http://www.forbes.com/sites/erikkain/2011/12/28/ridley-scotts-prometheusand-the-science-fiction-of-corporatism/\#265187fd212d (Accessed 31 May 2016).

Klein, G., 1995. Préface: science-fiction et prospective (Preface: science-fiction and forecasting). In: Brunner, J. (Ed.), Tous à Zanzibar. Original title: Stand on Zanzibar, 1968. Le Livre de Poche, Paris.

Knowles, J., Cole, A., 2008. Arts-informed research. In: Knowles, J.G., Cole, A.L. (Eds.), Handbook of the arts in qualitative research: perspective, methodologies, example and issues. Sage Publications, Thousand Oaks.

Koestler, A., 1970. The Act of Creation (Revised Danube Edition ed.). Pan Books,
London.

Le Moigne, J.L., 2012. Les épistémologies constructivistes (The Constructivist epistemologies). In: Que Sais-je? No 2969. Presses Universitaires de France.

Leavy, P., 2008. Method Meets Art: Arts-Based Research Practice. The Guilford Press. Lenoir, R., 1999. Objet sociologique et problème social (Sociological object and social problem). Dunod, Paris.

Lever-Tracy, C., 2008. Global warming and sociology. Curr. Sociol. 56 (3), 445-466.

Loewenstein, G., O’Donoghue, T., 2004. Animal Spirits: Affective and Deliberative Processes in Economic Behavior (May 4, 2004). http://dx.doi.org/10.2139/ ssrn.539843. Available at: SSRN: http://ssrn.com/abstract=539843.

Matten, D., Moon, J., 2013. Corporate citizenship: introducing business as an actor in political governance. In: Matten, D., Moon, J. (Eds.), Corporate Citizenship. Edward Elgar, Cheltenham.

McCormick, K., Neij, L., Mont, O., Ryan, C., Rodhe, H., Orsato, R., 2016. Advancing sustainable solutions: an interdisciplinary and collaborative research agenda. J. Clean. Prod. 123, 1-4.

McLean, J., 2004. Transnational corporation in history: Lessons for today. Indiana Law J. 79, 363.

Meppem, T., 2000. The discursive community: evolving institutional structures for planning sustainability. Ecol. Econ. 34 (1), 47-61.

Michaud, T., 2012. Lutilité de la sociologie pour comprendre le passage de limaginaire à linnovation dans les organisations. Cah. Rech. Sociol. 215-234.

Mills, C.W., 1959. The Sociological Imagination. Oxford University Press, New York.

Moylan, T., Baccolini, R. (Eds.), 2003. Dark Horizons: Science Fiction and the Dystopian Imagination. Routledge, New York, London.

Nicolescu, B., 1996. La Transdisciplinarité: Manifeste (The Transdisciplinarity: Manifesto). Éditions du Rocher.

Nicolescu, B., 2014. Methodology of transdisciplinarity. World Futur. 70 (3-4), 186-199.

Nisbet, R.A., 1968. The year 2000 and all that. Commentary 45 (6), 60.

Norris, C.B., Revéret, J.P., 2015. Partial organization and social LCA development: the creation and expansion of an epistemic community. In: Muthy, S.S. (Ed.), Social Life Cycle Assessment. Springer, Singapore, pp. 199-226.

Owens, J.W., 1998. Life cycle impact assessment: the use of subjective judgements in classification and characterization. Int. J. Life Cycle Assess. 3 (1), 43-46.

Rittel, H.W.J., Webber, M.M., 1973. Dilemmas in a general theory of planning. Pol Sci. 4, 155-173.

Rumpala, Y., 2010. Ce que la Science-Fiction Pourrait Apporter à la Pensée Politique (That science fiction could bring to the political thought). Raisons Politiques, pp. 97-114.

Schmidt, G., Beaujolin, R., Mourey, D., Bobadilla, N., Debenedetti, S., Mairesse, P., Xhauflair, V., 2015. Quand l'art parle de restructurations d'entreprises. Dévoilement des impensés et connaissance expérientielle. In: Annales des Mines-Gérer et comprendre, vol. 2. FFE, pp. 67-78.

Smith, W., Higgins, M., Parker, M., Lightfoot, G., 2003. Science Fiction and Organization. Routledge, London and New York.

Spiegel, M., 2010. Character in a post-national world: neomedievalism in Atwood's Oryx and Crake. Mosaic A J. Interdiscip. Study Lit. 43 (3), 119-134.

Sullivan, G., 2010. Art Practice as Research: inquiry in Visual Arts. Sage, Los Angeles.

Todorov, T., 1996. Goethe sur l'art : aimer Goethe (Goethe on art: Love Goethe). In: Goethe, J.W.v. (Ed.), Ecrits sur lart. Flammarion, Paris.

Touraine, A., 1977. The Self-Production of Society. The University of Chicago Press, Chicago.

Tukker, A., 2000. Philosophy of science, policy sciences and the basis of decision support with LCA Based on the toxicity controversy in Sweden and The Netherlands. Int. J. Life Cycle Assess. 5 (3), 177-186.

Veblen, T., 1921. The Engineers and the Price System. BW Huebsch, New York.

Yough-Bruehl, E., 2004. Hannah Arendt: for Love of the World. Yale University Press, New Haven \& London.

Zerilli, L.M.G., 2005. "We feel our freedom": imagination and judgment in the thought of Hannah Arendt. Polit. Theory 33 (2), 158-188. 